\title{
The killing of Helicobacter pylori by low-power laser light in the presence of a photosensitiser
}

\author{
C. E. MILLSON, M. WILSON*, A. J. MACROBERT, J. BEDWELL and S. G. BOWN \\ The National Medical Laser Centre, University College London Medical School, The Rayne Institute, 5 \\ University Street, London WC1E 6JJ and *Department of Microbiology, Eastman Dental Institute for Oral \\ Health Care Sciences, 256 Gray's Inn Road, London WC1X 8LD
}

\begin{abstract}
Helicobacter pylori is associated with various gastrointestinal disorders. Lethal photosensitisation was investigated as a possible technique for killing $H$. pylori which might offer a better alternative to antibiotics. The susceptibility of $\boldsymbol{H}$. pylori to lethal photosensitisation was determined by mixing suspensions of $\boldsymbol{H}$. pylori with various photosensitisers and plating out on blood agar before irradiation with low-power laser light. Five sensitisers were studied further by mixing them with $H$. pylori in a tissueculture plate and counting survivors after irradiation as a function of laser exposure time, dye concentration and pre-irradiation time. Crystal violet and thionin were ineffective as sensitisers, but zones of inhibition appeared with methylene blue (MB), protoporphyrin IX (PPIX), haematoporphyrin derivative (HPD), toluidine blue O (TBO) and disulphonated aluminium phthalocyanine (S2). Laser light or sensitiser alone did not affect bacterial viability. $S 2(100 \mu \mathrm{g} / \mathrm{ml})$ with a laser light energy density of $16 \mathrm{~J} /$ $\mathrm{cm}^{2}$, HPD $(100 \mu \mathrm{g} / \mathrm{ml})$ with $160 \mathrm{~J} / \mathrm{cm}^{2}, \mathrm{MB}(100 \mu \mathrm{g} / \mathrm{ml})$ with $21 \mathrm{~J} / \mathrm{cm}^{2}$, PPIX $(150 \mu \mathrm{g} / \mathrm{ml})$ with $320 \mathrm{~J} / \mathrm{cm}^{2}$ and TBO $(50 \mu \mathrm{g} / \mathrm{ml})$ with $160 \mathrm{~J} / \mathrm{cm}^{2}$ all reduced bacterial viability by $>99 \%$. The killing of sensitised $H$. pylori by laser light offers a new approach to the treatment of localised infections when all colonised areas are accessible to light.
\end{abstract}

\section{Introduction}

H. pylori has been found to be associated with type B gastritis, duodenal and gastric ulcers and, more recently, with carcinoma of the stomach [1-4]. Eradication of the bacteria leads to resolution of the histological and immunological changes associated with gastritis and a marked reduction in duodenal ulcer relapse rate $[5,6]$. This eradication is conventionally achieved with broadspectrum antibiotics, usually in conjunction with bismuth or omeprazole [6-8]. The most commonly recommended combination consists of bismuth, amoxycillin (or tetracycline) and metronidazole. Although these combination therapies may achieve eradication rates of over $80 \%$ [6], there are risks to the individual patient and the population in general through the widespread, prolonged use of broad-spectrum antibiotics and bismuth. These risks include rising rates of antibiotic resistance $[9,10]$ and alteration of the natural microflora at other sites; moreover bismuth compounds have specific neurotoxic side-effects [11].

Therefore, there is a need for an alternative means of killing $H$. pylori. One possible approach is to use

Received 1 Dec. 1994; revised version accepted 2 Sept. 1995.

Corresponding author: Dr M. Wilson. photodynamic therapy (PDT) which involves the killing of an organism by low-power laser light in the presence of a photosensitising agent. Excitation of the sensitiser by absorption of light of the appropriate wavelength converts the sensitiser to its photoactive triplet state, which in turn reacts with either a local substrate (type 1 reaction) to form cytotoxic radicals, or with molecular oxygen (type 2 reaction) to produce cytotoxic singlet oxygen $\left({ }^{1} \mathrm{O}_{2}{ }^{*}\right)[12,13]$.

H. pylori is usually found on the gastric mucosa, but will also seek out mucosa of gastric type elsewhere, i.e., metaplastic epithelium in the duodenum and Barrett's oesophagus. All these sites are accessible to an endoscope, which means that PDT could be a feasible alternative to antibiotic therapy.

The first demonstration of lethal photosensitisation of microbial cells was recorded nearly 100 years ago [14]. Subsequently, gram-positive and gram-negative bacteria, mycoplasmas, yeasts and viruses have all been shown to be susceptible to the technique [15-17]. In 1990, Bedwell et al. [18] reported that $H$. pylori can also be killed in this way with aluminium sulphonated phthalocyanine (a mixture of di-, tri- and tetra-sulphonated derivatives) as sensitiser and laser irradiation at $675 \mathrm{~nm}$. The purpose of the present study was to screen the disulphonated 
derivative and other compounds for their ability to sensitise $H$. pylori to killing by low-power laser light and to investigate the effects of parameters such as sensitiser concentration, time of exposure to sensitiser and light dose, on bacterial killing.

\section{Materials and methods}

\section{Organism}

H. pylori NCTC 11637-11 was used in the study. It was grown on blood agar plates for a period of $72 \mathrm{~h}$ in a micro-aerophilic atmosphere (Oxoid SR 056) and then suspended in Wilkins-Chalgren (WC) broth at neutral $\mathrm{pH}$ and vortex mixed to achieve a uniform suspension for these experiments.

\section{Laser sources and photosensitisers}

Seven photosensitisers were tested: toluidine blue $O$ (TBO; Sigma), haematoporphyrin derivative (HPD; Paisley Biochemicals, Glasgow), methylene blue (MB; Sigma), crystal violet (CV; Sigma), thionin (Sigma), protoporphyrin IX (PPIX, sodium salt; Sigma) and aluminium disulphonated phthalocyanine (S2; from Professor D. Phillips, Imperial College, London). Each sensitiser was prepared in WC broth and filter-sterilised immediately before use.

For S2 and $\mathrm{MB}$ an 11-mW gallium-aluminiumarsenide (GaAlAs) laser (Omega Fibres and Technology) was used. This emitted light with a wavelength of $660 \mathrm{~nm}$ and a beam diameter of $9 \mathrm{~mm}$, at a power density of $17 \mathrm{~mW} / \mathrm{cm}^{2}$. A $7.3-\mathrm{mW}$ helium-neon (HeNe) gas laser (NEC, Japan) was used with the other five sensitisers. This continuous wave laser emitted light with a wavelength of $632.8 \mathrm{~nm}$ in a beam with a diameter of $1.3 \mathrm{~mm}$, at a power density of $500 \mathrm{~mW} / \mathrm{cm}^{2}$.

\section{Determination of the effect of laser light on bacterial viability}

Screening assay. Two $\mathrm{ml}$ of the bacterial suspension were added to $2 \mathrm{ml}$ of sensitiser solution and mixed thoroughly. After incubation for $5 \mathrm{~min}, 1 \mathrm{ml}$ was spread over the surface of a dry modified blood agar (Blood Agar Base No. 2 with selective supplement SRO89E, Oxoid) plate which was then allowed to dry at $37^{\circ} \mathrm{C}$ before irradiation with light from a $\mathrm{HeNe}$ or GaAlAs laser for up to 5 or $30 \mathrm{~min}$, respectively $(1+\mathrm{s}+)$.

Control plates consisting of the bacterial suspension plus WC broth in place of the dye solution were treated in exactly the same fashion to determine the effect of the laser light alone on bacterial viability $(1+s-)$. A further two plates were prepared as above with bacterial suspension and dye but were not exposed to laser light $(l-s+)$. Hence, the effect on bacterial viability of the photosensitiser alone could be ascertained. Two plates consisting of the bacterial suspension and WC broth alone were left unirradiated $(\mathrm{l}-\mathrm{s}-)$.

Plates were incubated at $37^{\circ} \mathrm{C}$ for 3-5 days in a micro-aerophilic atmosphere and then examined for zones of inhibition of bacterial growth.

Quantitative assay. One hundred $\mu l$ of the bacterial suspension were pipetted into one well of a 96-well tissue-culture plate followed by $100 \mu \mathrm{l}$ of sensitiser in WC broth and a 4-mm sterile mixing bar. After mixing for various pre-irradiation times, the contents of the well were exposed to the laser light while mixing with the magnetic stirrer continued. At the end of the exposure period, $100 \mu \mathrm{l}$ were pipetted from the well into $900 \mu \mathrm{l}$ of sterile broth. Serial dilutions were then prepared according to the Miles and Misra technique and plated on to modified blood agar to determine the number of surviving organisms. Bacteria treated with both sensitiser and laser light were designated $(1+s+)$. Colony counts were performed after incubation of plates in a micro-aerophilic atmosphere for 5 days at $37^{\circ} \mathrm{C}$. All experiments were performed with minimal exposure to ambient light. Three variables were studied: sensitiser concentration, laser exposure time and pre-irradiation time (time of exposure of organism to sensitiser before irradiation with laser light). Control wells were arranged to observe the effect on bacteria of these three variables in isolation.

Effect of sensitiser concentration. To determine the minimum dye concentration capable of sensitising the organism to killing by the chosen dose of laser light, TBO and HPD were used at final sensitiser concentrations of 25,50 and $100 \mu \mathrm{g} / \mathrm{ml}$. MB and S2 were diluted to final concentrations of 10,50 and $100 \mu \mathrm{g} / \mathrm{ml}$. PPIX was diluted to final concentrations of 100,150 and $250 \mu \mathrm{g} / \mathrm{ml}$. The energy density used for PPIX, TBO and HPD was $160 \mathrm{~J} / \mathrm{cm}^{2}$ (5 min of laser exposure time), for S2 was $15 \mathrm{~J} / \mathrm{cm}^{2}$ (15 min exposure) and for MB was $21 \mathrm{~J} / \mathrm{cm}^{2}$. The pre-irradiation time (PIT) was $5 \mathrm{~min}$ for all sensitisers. Control wells were filled in the same way with $100 \mu \mathrm{l}$ of bacteria and $100 \mu \mathrm{l}$ of sensitiser in varying concentrations. They were not exposed to laser light but were mixed for the same period (PIT) as the test wells and were denoted $(1-s+)$. 'Light only' control wells were processed in an identical manner except that WC broth was added in place of sensitiser and the well was exposed to laser light $(1+s-)$. Additional controls consisted of unirradiated sensitiserfree $(1-s-)$ bacterial suspensions. Serial dilutions and plating out facilitated counting of survivors as for test wells.

Effect of laser light exposure time. The $\mathrm{HeNe}$ laser exposure time was increased to $10 \mathrm{~min}$ (energy density of $320 \mathrm{~J} / \mathrm{cm}^{2}$ ), with HPD $50 \mu \mathrm{g} / \mathrm{ml}$ and TBO $100 \mu \mathrm{g} / \mathrm{ml}$, and from 1 to $20 \mathrm{~min}\left(320 \mathrm{~J} / \mathrm{cm}^{2}\right)$ with PPIX $150 \mu \mathrm{g} / \mathrm{ml}$. 
GaAlAs laser exposure time was varied from 5 to $25 \mathrm{~min}\left(5-25 \mathrm{~J} / \mathrm{cm}^{2}\right)$ with an $\mathrm{S} 2$ concentration of $100 \mu \mathrm{g} / \mathrm{ml}$, and from 1 to $20 \mathrm{~min}\left(1-20 \mathrm{~J} / \mathrm{cm}^{2}\right)$ with MB $100 \mu \mathrm{g} / \mathrm{ml}$. The PIT was $5 \mathrm{~min}$ for all test and control wells. Control wells $(1-s-, 1+s-$ and $1-\mathrm{s}+$ ) were exposed to the non-culture environment for the same period as the longest laser exposure time. Light only wells $\left(1+s_{-}\right)$were exposed to the highest energy density used for the equivalent sensitiser.

Effect of pre-irradiation time. With a laser light exposure time of $5 \mathrm{~min}$ for TBO $(50 \mu \mathrm{g} / \mathrm{ml})$ and HPD $(100 \mu \mathrm{g} / \mathrm{ml})$ the PIT was varied from 0 to $30 \mathrm{~min}$. PIT was varied from 0 to $4 \mathrm{~h}$ with S2 at a concentration of $100 \mu \mathrm{g} / \mathrm{ml}$ (energy dose $15 \mathrm{~J} / \mathrm{cm}^{2}$ ) and from 0 to $3 \mathrm{~h}$ with MB $100 \mu \mathrm{g} / \mathrm{ml}$ (energy dose $21 \mathrm{~J} / \mathrm{cm}^{2}$ ) and $150 \mu \mathrm{g} /$ $\mathrm{ml}$ PPIX (energy dose $160 \mathrm{~J} / \mathrm{cm}^{2}$ ). Control wells $(1-s-, 1+s-, 1-s+)$ were exposed to the maximum PIT for the sensitiser under test.

Statistical analysis of the results was performed in the following way: each 'well' yielded two viable counts and two wells were used for each sample. A Student's $t$ test was performed on the data, comparing the mean count of each test well $(1+s+)$ with that of the unirradiated, sensitiser-free control $(1-s-)$. The two control wells $(1-\mathrm{s}+)$ and $(1+\mathrm{s}-)$ were also compared with the unirradiated sensitiser-free control $(1-s-)$.

\section{Results}

Irradiation of the bacteria with either laser for up to $30 \mathrm{~min}$ in the absence of a sensitiser had no detectable effect on the viability of the organism in any of the experiments. Similarly, at the concentration employed, TBO, MB, PPIX, HPD and S2 had no detectable effect on bacterial viability in the absence of laser light.

The results of the screening assay are given in Table 1. No zones of inhibition of bacterial growth were seen when $H$. pylori was irradiated with HeNe laser light in the presence of $\mathrm{CV}$ or thionin. However, zones of inhibition were seen when the organism was irradiated in the presence of TBO at a final concentration $50 \mu \mathrm{g} / \mathrm{ml}$, MB $100 \mu \mathrm{g} / \mathrm{ml}$, PPIX $150 \mu \mathrm{g} / \mathrm{ml}$, HPD $100 \mu \mathrm{g} / \mathrm{ml}$ and S2 $100 \mu \mathrm{g} / \mathrm{ml}$. Laser light alone caused areas of haemolysis on the blood agar plate. To control for any possible effect this may have had on bacterial growth, two plates were exposed to laser light prior to the bacteria being spread over the surface. There was no evidence of growth inhibition in the irradiated zones after incubation for 5 days.

The quantitative assessment of PPIX, S2, TBO, MB and HPD showed that only HPD at its highest concentration $(100 \mu \mathrm{g} / \mathrm{ml})$ had a significant effect on bacterial viability ( $33 \%$ reduction) in the absence of laser light at the concentrations used. Similarly, the laser light alone had no statistically significant effect on bacterial viability. The results of the quantitative assays with each sensitiser are given in Tables 2 to 6 and Table 7 was calculated with the minimum values required to achieve at least $\log _{10} 3$ reduction in bacterial numbers for each sensitiser. The efficacy of both TBO and PPIX were markedly improved by increasing their PIT, but varying the pre-irradiation time had no effect for the other photosensitisers. Table 8 gives the extinction coefficients for each of the seven sensitisers in WC broth at the wavelength used in the screening experiment.

\section{Discussion}

This study has shown that $H$. pylori can be killed by low doses of laser light after sensitisation with S2, PPIX, TBO, HPD or MB, but not after treatment with $\mathrm{CV}$ or thionin. Irradiation of $H$. pylori with light from either the HeNe or GaAlAs lasers, in the absence of sensitiser, had no effect on bacterial viability. A zone of inhibition on an agar plate may sometimes result from the killing of only a small number of organisms. However, the quantitative data confirmed an appreciable reduction in numbers of $H$. pylori when S2, HPD, PPIX, MB and TBO were used with the appropriate laser light source.

The apparent failure of $\mathrm{CV}$ and thionin to sensitise $H$. pylori may at first seem surprising, especially as thionin is structurally similar to TBO, a very effective

Table 1. Screening for lethal photosensitisation of $H$. pylori on the surface of agar plates after exposure to laser light, at the appropriate wavelength, in the presence of various test compounds

\begin{tabular}{|c|c|c|c|c|c|c|c|c|c|}
\hline \multirow[b]{2}{*}{ Sensitiser } & \multirow{2}{*}{$\begin{array}{l}\text { Concentration } \\
(\mu \mathrm{g} / \mathrm{ml})\end{array}$} & \multirow{2}{*}{$\begin{array}{c}\text { Wavelength } \\
(\mathrm{nm})\end{array}$} & \multicolumn{7}{|c|}{ Inhibition of growth at energy density $\left(\mathrm{J} / \mathrm{cm}^{2}\right)$} \\
\hline & & & 0.5 & 5 & $13-16$ & 31 & 66 & 320 & 960 \\
\hline TBO & 50 & 633 & - & - & - & - & + & + & + \\
\hline HPD & 100 & 633 & - & - & - & - & + & + & + \\
\hline $\mathrm{CV}$ & 100 & 633 & - & - & - & - & - & - & - \\
\hline Thionin & 100 & 633 & - & - & - & - & - & - & - \\
\hline PPIX & 150 & 633 & - & - & - & + & + & + & + \\
\hline $\mathrm{S} 2$ & 100 & 660 & - & - & + & + & + & + & + \\
\hline MB & 100 & 660 & - & + & + & + & + & + & + \\
\hline
\end{tabular}


Table 2. Viable counts in studies with TBO

\begin{tabular}{|c|c|c|c|c|c|c|}
\hline \multirow{2}{*}{ Test conditions } & \multirow[b]{2}{*}{ variable } & \multicolumn{4}{|c|}{ Viable count $(\mathrm{SD})\left(10^{7} \mathrm{cfu} / \mathrm{ml}\right)$} & \multirow{2}{*}{$\begin{array}{c}\log _{10} \text { reduction } \\
\text { in viable count } \\
\text { (Percent killed) }\end{array}$} \\
\hline & & $1-s-$ & $1+s-$ & $1-s+$ & $1+s+$ & \\
\hline $\begin{array}{l}\text { PIT }=5 \mathrm{~min} \\
\mathrm{ED}=160 \mathrm{~J} / \mathrm{cm}^{2}\end{array}$ & $\begin{array}{c}\begin{array}{c}\text { Conc } \\
(\mu \mathrm{g} / \mathrm{ml})\end{array} \\
10 \\
25 \\
50\end{array}$ & $28(25)$ & $35(25)$ & $\begin{array}{l}60(29) \\
43(18) \\
43(12)\end{array}$ & $\begin{array}{c}1.5(1.2)^{*} \\
0.2(0.04)^{*} \\
0.09(0.06)^{*}\end{array}$ & $\begin{array}{l}1.2(94.7) \\
2.5(99.6) \\
2.2(99.5)\end{array}$ \\
\hline $\begin{array}{l}\text { PIT }=5 \mathrm{~min} \\
\text { Conc }=50 \mu \mathrm{g} / \mathrm{ml}\end{array}$ & $\begin{array}{c}\mathrm{ED} \\
\left(\mathrm{J} / \mathrm{cm}^{2}\right) \\
32 \\
64 \\
160 \\
320\end{array}$ & $34(15)$ & $\begin{array}{c}\ldots \\
\ldots \\
28(12)\end{array}$ & $\begin{array}{c}\ldots \\
\ldots 2(6) \\
\ldots\end{array}$ & $\begin{aligned} 31(6) \\
23(6) \\
0.09(0.06)^{*} \\
0.2(0.15)^{*}\end{aligned}$ & $\begin{array}{ll}0 & \\
0.2(42) \\
2.5(99.6) \\
2.2(99.4)\end{array}$ \\
\hline $\begin{array}{l}\mathrm{ED}=160 \mathrm{~J} / \mathrm{cm}^{2} \\
\text { Conc }=100 \mu \mathrm{g} / \mathrm{ml}\end{array}$ & $\begin{array}{c}\text { PIT } \\
(\min ) \\
0.5 \\
5 \\
30\end{array}$ & $24(6)$ & $\begin{array}{c}\cdots \\
\cdots \\
28(8)\end{array}$ & $27 \cdots$ & $\begin{array}{c}0.7(0.2)^{* *} \\
0.2(0.1)^{* *} \\
0.001(0.001)^{* *}\end{array}$ & $\begin{array}{cc}1.5 & (96.9) \\
2 & (99.1) \\
>4 & (99.9)\end{array}$ \\
\hline
\end{tabular}

Bacterial suspensions were irradiated in the presence $(1+s+)$ or absence $(1+s-)$ of the test compound. Additional controls consisted of unirradiated suspensions in the presence $(1-s+)$ or absence $(1-s-)$ of the test compound. ED, energy density; PIT, pre-irradiation time; Conc, sensitiser concentration.

${ }^{*}$ Denotes significant difference between control $(1-\mathrm{s}-)$ and test sample $\left({ }^{*} \mathrm{p}<0.05,{ }^{* *} \mathrm{p}<0.001,2\right.$-tail $t$ test $)$. When ED was varied, $1+\mathrm{s}-$ was tested for maximum ED only.

Table 3. Viable counts in studies with HPD

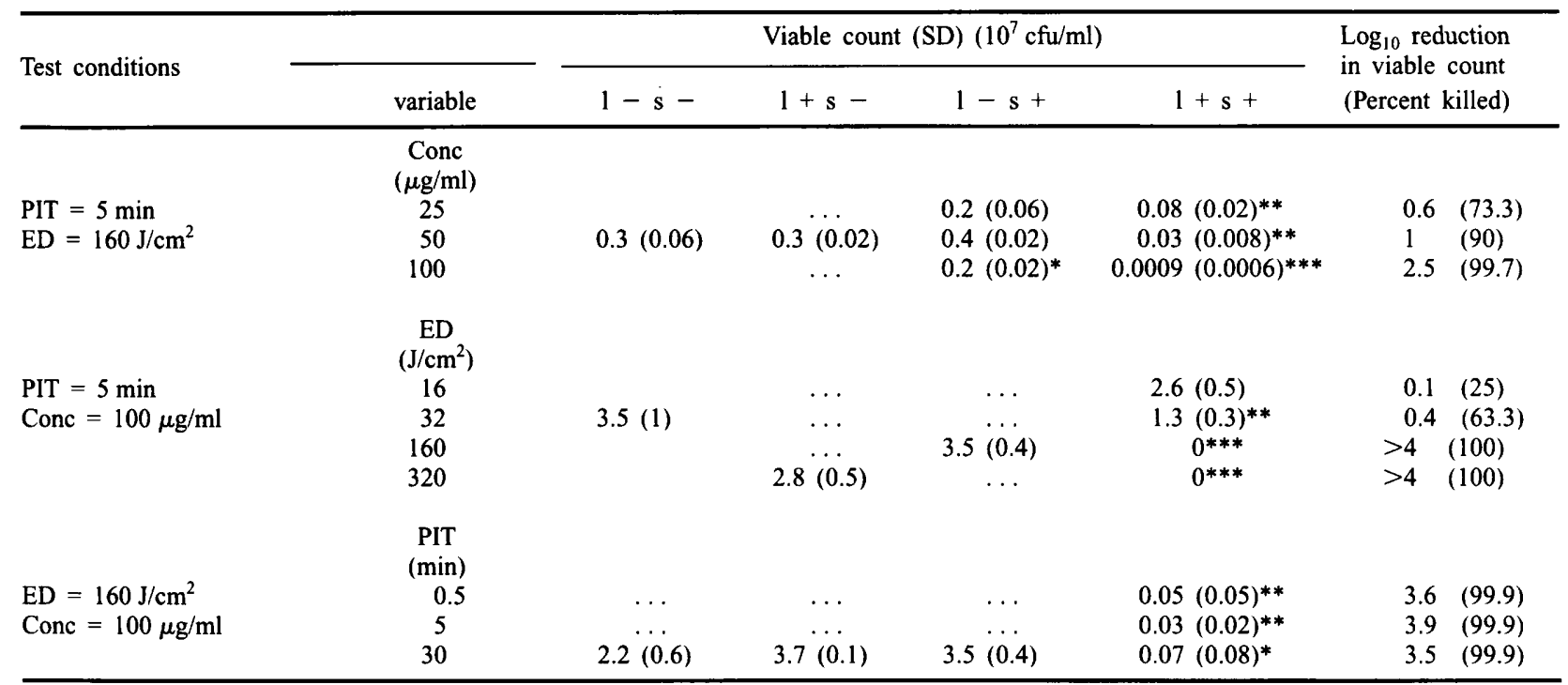

See footnote to Table 2 .

${ }^{*}$ Denotes significant difference between control $(1-\mathrm{s}-)$ and test sample $\left({ }^{*} \mathrm{p}<0.05,{ }^{* *} \mathrm{p}<0.001,{ }^{* * *} \mathrm{p}<0.0001,2\right.$-tail $t$ test $)$.

photosensitiser of this organism. However, the efficacy of any sensitiser is dictated by its light absorbance at the wavelength emitted by the light source. Table 8 shows the extinction coefficients of each of the seven sensitisers, at the appropriate laser wavelength. Although thionin and CV do have a low absorbance at the wavelength used, there must be other factors involved (such as sensitiser uptake by the organism) as the value for HPD is also low and yet it was found to be a very effective photosensitiser.

The viability of cultures of TBO-treated $H$. pylori was substantially reduced by exposure to light from a HeNe laser. The dye itself was found to have no toxic effect on $H$. pylori in the absence of laser light.
However, in combination, a dose-dependent effect was seen with respect to both laser energy dose and sensitiser concentration. MacMillan et al. [19], amongst others, have reported successful lethal photosensitisation of both gram-positive (Sarcina lutea) and gram-negative (Escherichia coli) bacteria with TBO and $\mathrm{HeNe}$ laser light. Similarly, Wilson and Mia [20] have achieved killing of TBO-sensitised Candida albicans by exposure to laser light. The energy doses for lethal photosensitisation of various organisms were $160 \mathrm{~J} / \mathrm{cm}^{2}$ for $H$. pylori, $16 \mathrm{~J} / \mathrm{cm}^{2}$ for periodontopathogens Fusobacterium nucleatum, Porphyromonas gingivalis [21] and Actinobacillus actinomycetemcomitans and $48 \mathrm{~J} / \mathrm{cm}^{2}$ for $C$. albicans, with the same concentration of TBO $(50 \mu \mathrm{g} / \mathrm{ml})$. 
Table 4. Viable counts in studies with S2

\begin{tabular}{|c|c|c|c|c|c|c|}
\hline \multirow{2}{*}{ Test conditions } & \multirow[b]{2}{*}{ variable } & \multicolumn{4}{|c|}{ Viable count $(\mathrm{SD})\left(10^{7} \mathrm{cfu} / \mathrm{ml}\right)$} & \multirow{2}{*}{$\begin{array}{l}\log _{10} \text { reduction } \\
\text { in viable count } \\
\text { (Percent killed) }\end{array}$} \\
\hline & & $1-s-$ & $1+s-$ & $1-s+$ & $1+s+$ & \\
\hline $\begin{array}{l}\mathrm{PIT}=15 \mathrm{~min} \\
\mathrm{ED}=15 \mathrm{~J} / \mathrm{cm}^{2}\end{array}$ & 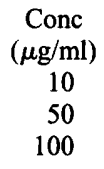 & $8.6(2.6)$ & $\begin{array}{c}\dot{8}(3.1) \\
\ldots\end{array}$ & $\begin{array}{r}9(1.1) \\
11(2.7) \\
9.9(0.4)\end{array}$ & $\begin{array}{c}0.03(0.005)^{* *} \\
0.04(0.04)^{* *} \\
0.8(0.1)^{* *}\end{array}$ & $\begin{array}{rr}>4 & (99.9) \\
>4 & (99.9) \\
3.0 & (99.9)\end{array}$ \\
\hline $\begin{array}{l}\text { PIT }=15 \mathrm{~min} \\
\text { Conc }=100 \mu \mathrm{g} / \mathrm{ml}\end{array}$ & $\begin{array}{c}E D \\
\left(\mathrm{~J} / \mathrm{cm}^{2}\right) \\
5 \\
15 \\
20 \\
25\end{array}$ & $23(5.6)$ & $\begin{array}{c}\cdots \\
\cdots \\
20(5.6)\end{array}$ & $\begin{array}{c}\ldots \\
22(4.8) \\
\ldots\end{array}$ & $\begin{array}{c}0.8(0.03)^{* *} \\
0.2(0.09)^{* *} \\
0.2(0.03)^{* *} \\
0.07(0.007)^{* *}\end{array}$ & $\begin{array}{rr}2.5 & (96.5) \\
& 4.0(99.9) \\
> & 4 \quad(99.9) \\
> & 4 \quad(99.9)\end{array}$ \\
\hline $\begin{array}{l}\mathrm{ED}=15 \mathrm{~J} / \mathrm{cm}^{2} \\
\text { Conc }=100 \mu \mathrm{g} / \mathrm{ml}\end{array}$ & $\begin{array}{c}\text { PIT } \\
(\mathrm{min}) \\
0 \\
60 \\
240\end{array}$ & $\begin{array}{c}\cdots \\
\cdots \\
2.2(0.8)\end{array}$ & $\begin{array}{c}\cdots \\
2.3(1.2)\end{array}$ & $\begin{array}{c}\cdots \\
0.9(0.4)\end{array}$ & $\begin{array}{c}0.006(0.002)^{* *} \\
0.002(0.001)^{* *} \\
0.03(0.02)^{* *}\end{array}$ & $\begin{array}{rr}>4 & (99.9) \\
>4 & (99.9) \\
3.9 & (99.9)\end{array}$ \\
\hline
\end{tabular}

See footnote to Table 2 .

${ }^{*}$ Denotes significant difference between control $(1-\mathrm{s}-)$ and test sample $\left({ }^{*} \mathrm{p}<0.05,{ }^{* *} \mathrm{p}<0.001,{ }^{* * *} \mathrm{p}<0.0001,2\right.$-tail $t$ test).

Table 5. Viable counts in studies with PPIX

\begin{tabular}{|c|c|c|c|c|c|c|}
\hline \multirow{2}{*}{ Test conditions } & \multirow[b]{2}{*}{ variable } & \multicolumn{4}{|c|}{ Viable count $(\mathrm{SD})\left(10^{7} \mathrm{cfu} / \mathrm{ml}\right)$} & \multirow{2}{*}{$\begin{array}{l}\log _{10} \text { reduction } \\
\text { in viable count } \\
\text { (Percent killed) }\end{array}$} \\
\hline & & $1-s-$ & $1+s-$ & $1-s+$ & $1+s+$ & \\
\hline $\begin{array}{l}\mathrm{PIT}=5 \mathrm{~min} \\
\mathrm{ED}=160 \mathrm{~J} / \mathrm{cm}^{2}\end{array}$ & $\begin{array}{c}\text { Conc. } \\
(\mu \mathrm{g} / \mathrm{ml}) \\
100 \\
150 \\
250\end{array}$ & $64(21)$ & $\begin{array}{c}56 \dot{(37)} \\
\ldots\end{array}$ & $\begin{array}{l}66(38) \\
76(27) \\
68(8)\end{array}$ & $\begin{array}{l}15(3)^{*} \\
0.9(0.5)^{* *} \\
0.6(0.09)^{* *}\end{array}$ & $\begin{array}{ll}0.6 & (76.6) \\
1.9 & (99.1) \\
2.1 & (99.1)\end{array}$ \\
\hline $\begin{array}{l}\text { PIT }=5 \mathrm{~min} \\
\text { Conc }=100 \mu \mathrm{g} / \mathrm{ml}\end{array}$ & $\begin{array}{c}E D \\
\left(\mathrm{~J} / \mathrm{cm}^{2}\right) \\
160 \\
320 \\
640\end{array}$ & $23(6)$ & $\begin{array}{c}\cdots \\
\cdots \\
23(4)\end{array}$ & $\begin{array}{c}\ldots \\
9(2) \\
\ldots\end{array}$ & $\begin{array}{c}0.05^{* *} \\
0.001(0.0003)^{* * *} \\
0 * * *\end{array}$ & 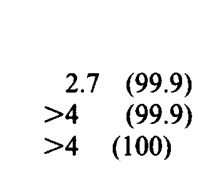 \\
\hline $\begin{array}{l}\mathrm{ED}=160 \mathrm{~J} / \mathrm{cm}^{2} \\
\text { Conc }=100 \mu \mathrm{g} / \mathrm{ml}\end{array}$ & $\begin{array}{c}\text { PIT } \\
\text { (min) } \\
0 \\
30 \\
180\end{array}$ & $\begin{array}{c}\cdots \\
44(18)\end{array}$ & $\begin{array}{c}\cdots \\
28(4)\end{array}$ & $\begin{array}{c}\cdots \\
6 \dot{(38)}\end{array}$ & $\begin{array}{c}3(1.2)^{*} \\
0.05(0.02)^{* *} \\
0.02(0.007)^{* *}\end{array}$ & $\begin{array}{ll}1.2 & (93.2) \\
1.9 & (99.9) \\
2.3 & (99.9)\end{array}$ \\
\hline
\end{tabular}

See footnote to Table 2 .

${ }^{*}$ Denotes significant difference between control $(1-\mathrm{s}-)$ and test sample $\left({ }^{*} \mathrm{p}<0.05,{ }^{* *} \mathrm{p}<0.001,{ }^{* * *} \mathrm{p}<0.0001,2\right.$-tail $t$ test).

Table 6. Viable counts in studies with MB

\begin{tabular}{|c|c|c|c|c|c|c|}
\hline \multirow{2}{*}{ Test conditions } & \multirow[b]{2}{*}{ variable } & \multicolumn{4}{|c|}{ Viable count $(\mathrm{SD})\left(10^{7} \mathrm{cfu} / \mathrm{ml}\right)$} & \multirow{2}{*}{$\begin{array}{l}\log _{10} \text { reduction } \\
\text { in viable count } \\
\text { (Percent killed) }\end{array}$} \\
\hline & & $1-s-$ & $1+s-$ & $1-s+$ & $1+s+$ & \\
\hline & $\begin{array}{c}\text { Conc } \\
(\mu \mathrm{g} / \mathrm{ml})\end{array}$ & & & & & \\
\hline $\mathrm{PIT}=5 \mathrm{~min}$ & 10 & & & $730(150)$ & $72(12)^{*}$ & $1.0(90.8)$ \\
\hline \multirow[t]{3}{*}{$\mathrm{ED}=21 \mathrm{~J} / \mathrm{cm}^{2}$} & 50 & $790(220)$ & $650(180)$ & $660(160)$ & $6.8(1.0)^{* *}$ & $2.1(99.1)$ \\
\hline & 100 & & $\ldots$ & $740(210)$ & $0.34(0.04)^{* * *}$ & $3.4(99.9)$ \\
\hline & $\begin{array}{c}\mathrm{ED} \\
\left(\mathrm{J} / \mathrm{cm}^{2}\right)\end{array}$ & & & & & \\
\hline $\mathrm{PIT}=10 \mathrm{~min}$ & 1 & & $\cdots$ & $\ldots$ & $5(1)$ & $0.5(69)$ \\
\hline \multirow[t]{4}{*}{ Conc $=100 \mu \mathrm{g} / \mathrm{ml}$} & 5 & $16(4)$ & $\ldots$ & $\ldots$ & $2.3(0.5)^{* *}$ & $0.8(85.6)$ \\
\hline & 10 & & $\ldots$ & $16(2)$ & $0.9(0.1)^{* * *}$ & $1.2(95.0)$ \\
\hline & 21 & & $14(3)$ & $\ldots$ & $0.04(0.01)^{* * *}$ & $2.6(99.8)$ \\
\hline & $\begin{array}{c}\text { PIT } \\
(\min )\end{array}$ & & & & & \\
\hline $\mathrm{ED}=10 \mathrm{~J} / \mathrm{cm}^{2}$ & 0 & $\ldots$ & $\ldots$ & $\ldots$ & $1.4(0.3)^{* *}$ & $1.2(93)$ \\
\hline \multirow[t]{2}{*}{ Conc $=100 \mu \mathrm{g} / \mathrm{ml}$} & 10 & $\ldots$ & $\ldots$ & $\ldots$ & $1.0(0.01)^{* *}$ & $1.3(95.4)$ \\
\hline & 90 & $20(2)$ & $20(2)$ & $19(2)$ & $1.1(0.03)^{* *}$ & $1.3(95)$ \\
\hline
\end{tabular}

See footnote to Table 2 .

${ }^{*}$ Denotes significant difference between control $(1-\mathrm{s}-)$ and test sample $\left({ }^{*} \mathrm{p}<0.05,{ }^{* *} \mathrm{p}<0.001,{ }^{* * *} \mathrm{p}<0.0001,2\right.$-tail $t$ test). 
Table 7. Comparison of all five sensitisers by calculation of the PDT dose required to cause a $\log _{10} 3$ reduction in cfu of $H$. pylori

\begin{tabular}{lccccr}
\hline Sensitiser & Mol. wt & $\begin{array}{c}\text { Concentration } \\
(\mathrm{M})\end{array}$ & $\begin{array}{c}\text { Energy density } \\
\left(\mathrm{J} / \mathrm{cm}^{2}\right)\end{array}$ & $\begin{array}{c}\text { PDT dose } \\
\left(\mathrm{MJ}^{2} \mathrm{~cm}^{2}\right)\end{array}$ & Ratio* $^{*}$ \\
\hline S2 & 770 & $1.30 \times 10^{-5}$ & 15 & $2.1 \times 10^{-4}$ & 1 \\
MB & 348 & $2.87 \times 10^{-4}$ & 21 & $6.0 \times 10^{-3}$ & 29 \\
TBO & 305 & $1.64 \times 10^{-4}$ & 160 & 0.026 & 124 \\
HpD & 600 & $1.67 \times 10^{-4}$ & 160 & 0.027 & 129 \\
PPIX & 607 & $2.47 \times 10^{-4}$ & 320 & 0.079 & 376 \\
\hline
\end{tabular}

PDT dose was the product of concentration and energy dose for each sensitiser

*PDT doses required for each sensitiser compared with that required for S2.

Table 8. Extinction coefficient values for the seven sensitisers at the wavelength used in this study

\begin{tabular}{lcc}
\hline Sensitiser & $\begin{array}{c}\text { Wavelength of } \\
\text { laser }(\mathrm{nm})\end{array}$ & $\begin{array}{c}\text { Extinction coefficient } \\
(\mathrm{M} / \mathrm{cm})\end{array}$ \\
\hline Thionin & 633 & 2900 \\
HpD & 633 & 3000 \\
CV & 633 & 5300 \\
PPIX & 633 & 13600 \\
TBO & 633 & 30000 \\
S2 & 660 & 20800 \\
MB & 660 & 45900 \\
\hline
\end{tabular}

HPD was shown to exhibit some toxicity to $H$. pylori in the absence of laser light. However, this dark toxicity was seen only at $100 \mu \mathrm{g} / \mathrm{ml}$, and has not been found by others [22]; its significance is not clear. A dose-dependent killing of sensitised bacteria was observed with respect to laser exposure time, as for TBO. HPD has been shown to be an effective photosensitiser of other gram-negative organisms, and Wolfson et al. [22] have recently reported successful lethal photosensitisation of $H$. pylori attached to a gastric carcinoma cell line (Kato III) with $\mathrm{HpD}$, at the same concentration as in the present study, and energy doses of between 1 and $10 \mathrm{~J} / \mathrm{cm}^{2}$ supplied by a $200 \mathrm{~W}$ Xenon arc lamp (with a 515-nm long pass filter). This concurs with the results presented here, where an energy dose of $66 \mathrm{~J} / \mathrm{cm}^{2}$ resulted in a $100 \%$ kill. They also found that uptake of the sensitiser was effectively instantaneous. The efficacy of three of the five sensitisers investigated in this study was shown to be similarly unaffected by pre-irradiation time, although for TBO and PPIX, increasing the pre-irradiation time did increase the bacterial kill. However, as the uptake of sensitiser may occur at any time during laser exposure and the laser exposure time was $5 \mathrm{~min}$ for HPD, PPIX and TBO, $15 \mathrm{~min}$ for S2 and $20 \mathrm{~min}$ for $\mathrm{MB}$, the uptake cannot be said to be instantaneous on the basis of the data from this study.

For aluminium disulphonated phthalocyanine (S2), the energy density necessary to kill $99 \%$ of bacteria (31 $\mathrm{J} / \mathrm{cm}^{2}$ ), was much lower than that necessary to kill the same number with TBO, PPIX and HpD with the $\mathrm{HeNe}$ laser $\left(160 \mathrm{~J} / \mathrm{cm}^{2}\right)$ with comparable concentrations of photosensitiser. This may be explained by the differences in their extinction coefficients. One other report [18] described successful lethal photosensitisa- tion of $H$. pylori with aluminium sulphonated phthalocyanine (mean sulphonation of three) as a sensitiser. In their experiment, $H$. pylori was incubated with the phthalocyanine for $4 \mathrm{~h}$ before exposure to laser light for a further $300 \mathrm{~s}$ from a copper vapour pumped dye laser at $675 \mathrm{~nm}$. Their phthalocyanine was a mixture of sulphonated derivatives whereas this study employed a pure S2 compound.

Table 5 shows that higher energy doses of up to 320 $\mathrm{J} / \mathrm{cm}^{2}$ are necessary to achieve orders of bacterial killing with PPIX similar to those of other sensitisers. Such a high energy dose raises the question of potential damage to the underlying mucosa, and any in vivo experimental work would require over-irradiation of mucosa to define the limits of safety with respect to light doses. PPIX is one of the compounds produced during haem synthesis and will accumulate for a few hours before its conversion to haem if the pathway is saturated by bypassing the previous rate limiting step, which is the production of 5 -amino laevulinic acid (ALA) by administration of excess exogenous ALA [23]. Regula et al. [24] demonstrated mucosal extraglandular fluorescence in human colonic and gastric mucosa $7-9 \mathrm{~h}$ after oral ALA administration which they concluded was evidence of PPIX excretion from the cells. As $H$. pylori congregate close to the mucosal surface it is possible that they could be exposed to PPIX.

The photochemistry and photobiology of MB has been reviewed recently as this particular histological dye has been known to be an effective sensitiser for use in PDT for over 60 years [25]. Micro-organisms already known to be photo-inactivated by MB include herpes viruses, HIV and many other viruses, Proteus mirabilis, E. coli and Salmonella typhimurium [25]. Also, Karita et al. [26] reported that MB was effective against $H$. pylori in vivo, without light activation, in their nude mouse model. Even though they achieved only a modest reduction in viable counts of bacteria, their data indicate that the sensitiser could access the bacteria after oral dosing. Dark toxicity was not found with the much lower concentrations used in the present study $(50$ and $500 \mu \mathrm{g} / \mathrm{ml})$ whereas Karita et al. employed a MB concentration of $3 \mathrm{mg} / \mathrm{ml}$.

Table 7 compares the efficacy of each sensitiser by 
calculating the 'PDT dose' (the product of the molar concentration and light dose) required to produce a $\log _{10}$ kill of $>3$. On this basis, $S 2$ and MB would appear to be the most effective agents, followed by TBO and HpD, and finally PPIX. Cost alone might favour MB over $\mathrm{S} 2$, especially as $\mathrm{MB}$ is already used in the treatment of the rare blood disorder methaemoglobinaemia. It has been used for delineating regions of dysplasia in the stomach and is approved for clinical use. However, both TBO and MB are anionic, and along with other dyes in the phenothiazinium group bind tightly to DNA, hence their use as histological stains. Therefore, the principal target for photosensitised biological action with these agents may be DNA, which means that the resulting damage could include alterations to DNA with the worrying possibility of mutagenicity. This must be addressed before undertaking any clinical studies. Nevertheless, others have suggested that TBO does not have this same mutagenic potential as its site of action is primarily the cytoplasmic membrane rather than the nucleus [25].

It is generally accepted that the type II reaction involving production of singlet oxygen $\left({ }^{1} \mathrm{O}_{2}{ }^{*}\right)$ is the most effective mechanism of oxygen-dependent cytotoxicity in PDT in mammalian cells [27] and that this reaction is involved with the membrane-bound photosensitisers S2, HPD and PPIX. However, the presence in prokaryotic and eukaryotic cells of high concentrations of reducing agents such as $\mathrm{NAD}(\mathrm{P}) \mathrm{H}$ and glutathione could favour a type 1 mechanism, so those sensitisers that gain access to the cytoplasm may act via one or both pathways. Experiments with MB aimed at protecting $E$. coli from lethal photosensitisation by employing free radical and superoxide scavengers suggest that both pathways are important, but similar work with $S$. lutea points towards singlet oxygen as the sole agent responsible [25]. In conclusion, it seems likely that each bacterial sensitiser interaction will be specific in its site of action and primary mechanism.

The results of this study have shown that $H$. pylori can be killed by low-power laser light following sensitisation with HPD, TBO, MB, PPIX or S2. The strain used in these experiments was laboratory adapted and clinical isolates might exhibit different sensitivities. However, the study demonstrated the successful killing of a gram-negative bacterium without the need for the membrane disrupting agents required with other gram-negative organisms [15, 21]. Given that $H$. pylori only colonises those areas of the upper gastrointestinal tract that are accessible to the endoscope and that energy doses required to effect bacterial killing are small, a local treatment for $H$. pylori becomes a possibility. The discussion above described how PPIX and MB are likely to be able to get to the regions colonised by $H$. pylori. Another recent publication [28] shows that some minor histological changes can be produced by spraying HPD on to the gastric mucosa of pigs followed by light treatment, suggesting that HPD can also be absorbed locally in the stomach and so get to the site of $H$. pylori colonisation. As three of the five successful sensitisers have been shown to gain access to the areas and level of the stomach where $H$. pylori is found, further investigation of this particular application of PDT is justifiable [24, 26, 28].

There are rodent data (our own unpublished observations) that suggest that gastric mucosa sensitised with MB would be unaffected by the energy doses used in this study as well as preliminary data from the pig model that elicited only minor and reversible histological changes in gastric mucosa sprayed with HPD and subsequently exposed to energy doses of $100 \mathrm{~J} /$ $\mathrm{cm}^{2}$ [28]. No such data exist for man, but doses are likely to be comparable. Clearly there are difficulties that would have to be overcome. Much further work is required to see if drug and light doses can be found that can eradicate the bacteria in vivo without unacceptable damage to the underlying mucosa. Even if this can be done, there is the major technical challenge of delivering adequate light doses to all areas of potentially infected mucosa. It would not be feasible for the same light dose to be delivered to all areas, but it is more important that a minimum light dose reaches every relevant site as excess light is unlikely to cause harmful effects. Some form of balloon to flatten mucosal folds in the stomach which also acts as a diffuse light source could provide a solution. The potential advantage of such a local therapy for $H$. pylori infection and the low likelihood of resistance developing suggest that further investigation of this technique is warranted.

This project was funded by the Sir Jules Thorn Charitable Trust. S.G.B. is funded by the Imperial Cancer Research Fund. We also thank Professor D. Phillips (Imperial College, London), who kindly provided the phthalocyanine.

\section{References}

1. Eurogast Study Group. An international association between Helicobacter pylori infection and gastric cancer. Lancet 1993; 341: $1359-1362$.

2. Marshall B. Unidentified curved bacilli on gastric epithelium in active chronic gastritis. Lancet 1983; 1: 1273-1275.

3. Vaira D, Holton J, Dowsett J, Oderda G, Barbara L. Helicobacter pylori: its role in gastric disease. Dig Dis 1990; 8: 322-336.

4. Moss S, Calam J. Helicobacter pylori and peptic ulcers: the present position. Gut 1992; 33: 289-292.

5. Chiba N, Babu R, Rademaker J et al. Meta-analysis of the efficacy of antibiotic therapy in eradicating $H$. pylori. Lancet 1992; 87: 1716-1726.

6. Rauws EA, Tytgat GNJ. Cure of duodenal ulcer associated with eradication of Helicobacter pylori. Lancet 1990; 335: 1233-1235.

7. Graham DY, Lew GM, Evans DG, Evans DG Jr, Klein PD. Effect of triple therapy (antibiotics plus bismuth) on duodenal ulcer healing. A randomized controled study. Ann Intern Med 1991; 115: 266-269. 
8. Unge $\mathrm{P}, \mathrm{Gad} \mathrm{A}$, Eriksson $\mathrm{K}$ et al. Amoxycillin added to omeprazole prevents relapse in the treatment of duodenal ulcer patients. Eur $J$ Gastroenterol Hepatol 1993; 5: 325-331.

9. Graham DY, Lew GM, Malaty HM et al. Factors influencing the eradication of Helicobacter pylori with triple therapy. Gastroenterology 1992; 102: 493-496.

10. Logan RPH, Gummett PA, Misiewicz JJ, Karim QM, Walker $\mathrm{MM}$, Baron JH. One week eradication regimen for Helicobacter pylori. Lancet 1991; 338: 1249-1252.

11. Gorbach SL. Bismuth therapy in gastrointestinal diseases. Gastroenterology 1990; 99: 863-875.

12. Manyak MJ. Photodynamic therapy: present concepts and future applications. Cancer $J$ 1990; 3: 104-109.

13. Pass HI. Photodynamic therapy in oncology: mechanisms and clinical use. J Natl Cancer Inst 1993; 85: 443-456.

14. Raab $O$. Uber die Wirkung fluorescierenden stoffe auf infusorierien. Z Biol 1990; 39: 524-546.

15. Malik Z, Hanania J, Nitzan Y. Bactericidal effects of photoactivated porphyrins - an alternative approach to antimicrobial drugs. J Photochem Photobiol 1990; 5: 281-293.

16. Wilson M. Photolysis of oral bacteria and its potential use in the treatment of caries and periodontal disease. $J$ Appl Bacteriol 1993; 75: 299-306.

17. Felber TD, Smith EB, Knox JM, Wallis C, Melnick JL. Photodynamic inactivation of Herpes simplex. Report of a clinical trial. JAMA 1973; 223: 289-292.

18. Bedwell J, Holton J, Vaira D, MacRobert AJ, Bown SG. In vitro killing of Helicobacter pylori with photodynamic therapy. Lancet 1990; 335: 1287.

19. MacMillan JD, Maxwell WA, Chichester CO. Lethal photosensitization of microorganisms with light from a continuouswave gas laser. Photochem Photobiol 1966; 5: 555-565.
20. Wilson M, Mia N. Sensitisation of Candida albicans to killing by low-power laser light. J Oral Pathol Med 1993; 22: 354 357.

21. Wilson M, Dobson J, Sarkar S. Sensitisation of periodontopathogenic bacteria to killing by light from a low-power laser. Oral Microbiol Immunol 1993; 8: 182-187.

22. Wolfsen $\mathrm{H}$, Wang, $\mathrm{K}$, Alquist $\mathrm{D}$ et al. Light dosimetry in PDT for Helicobacter pylori. In: Spinelli P, Dal Fante M, Marchesini R (eds) PDT and biomedical lasers. Amsterdam, Elsevier Science Publishers B.V. 1992: 281-285.

23. Bedwell J, MacRobert AJ, Phillips D, Bown SG. Fluorescence distribution and photodynamic effect of ALA-induced PPIX in the DMH rat colonic tumour model. $B r J$ Cancer 1992; 65: 818-824

24. Regula J, MacRobert AJ, Gorchein A et al. Photosensitisation and photodynamic therapy of oesophageal, duodenal, and colorectal tumours using 5 aminolaevulinic acid induced protoporphyrin IX - a pilot study. Gut 1995; 36: 67-75.

25. Tuite EM, Kelly JM. Photochemical interactions of methylene blue and analogues with DNA and other biological substrates. $J$ Photochem Photobiol B 1993; 21: 103-124.

26. Karita $M, L i$, Okita $K$. Evaluation of new therapy for eradication of $H$. pylori infection in nude mouse model. $A m J$ Gastroenterol 1993; 88: 1366-1372.

27. Moan J, Berg K, Kvam E. Effects of photodynamic treatment on DNA and DNA-related cell functions. In: Kessel D (ed) Photodynamic therapy of neoplastic disease, vol 1. Boca Raton, CRC press. 1992: 197-209.

28. Wolfsen HC, Wang $K$. Tolerance of normal swine gastric epithelium to photodynamic therapy using topically applied haematoporphyrin derivative. Lasers Surg Med 1993; Suppl 5: A364. 